\title{
Estimation of prevalence of red cell alloantibodies in patients with Beta Thalassaemia Major in Sri Lanka
}

\author{
Samantha Senavirathna ${ }^{1}$, Lakmali Ranasinghe ${ }^{1}$, Yashobha Thilakarathne ${ }^{1}$ \\ (Index words: red cell antibodies, antibody prevalence, transfusion reactions, thalassaemia major, unexpected \\ antibodies)
}

\begin{abstract}
Background and objectives: Major beta thalassaemia is an inherited haemolytic disease that needs regular blood transfusion as a standard treatment. Blood transfusion is generally safe; however, adverse effects can occur and one of which is red cell alloimmunization that can lead to acute or delayed haemolytic transfusion reactions. This study was designed to estimate the prevalence of red cell alloantibodies in patients with thalassaemia in Sri Lanka.

Methods: The study was carried out at three tertiary care hospitals of Sri Lanka. Every beta thalassaemia patients transfused with packed red cells were included. Data collected to a form by analysing the cross match request form sent to the blood bank prior to the transfusion.

Results: There were 398 patients in all hospitals. 188 (47.24\%) of them were males and 210 (52.76\%) were females. Mean age was $18.41(S D=11.67)$ years. Out of 398 patients, unexpected red cell antibodies are present only in $6(1.51 \%)$ patients. Identified antibodies were Anti $\mathrm{E}$, Anti K, Anti D, Anti C, Anti S, Anti Jk ${ }^{\mathrm{b}}$ and autoantibodies. There was one patient who had developed multiple antibodies.

Conclusion: Prevalence of red cell antibodies is lower, even though the patients were been transfused without phenotypically matched red cells. Further studies are suggested to decide the practice of Rh and Kell matching for transfusion in patients with beta thalassaemia.
\end{abstract}

\section{Introduction}

Major beta thalassaemia is an inherited haemolytic disease caused by the abnormal production of haemoglobin. In the absence of stem cell transplantation, these patients need regular blood transfusion as a standard treatment. Red cell transfusion can improve oxygen carrying capacity and reduces the abnormal erythropoiesis in those patients.

Although blood transfusion is generally safe, adverse effects can occur including haemolytic transfusion reactions, febrile non haemolytic transfusion reactions, immune mediated complications, iron overload and transfusion associated infections [1]. Minor less severe transfusion reactions are more common and significant or fatal transfusion reactions are rare [2]. Red cell alloimmunization can occur when the red cell recipients are exposed to the antigens that they do not possess. These alloantibodies can cause acute or delayed haemolytic transfusion reactions [1]. If red cell alloantibodies are formed it makes the compatibility testing more difficult as antigen negative blood must be provided for the corresponding antibody [3]. In addition to red cell antibodies there is risk of developing auto antibodies. In Sri Lanka 11 cases of delayed haemolytic transfusion reactions were reported in 2017 due to red cell antibodies. Most of them were Rh antibodies and others included in Kidd, Duffy and Kell blood group systems [4]. Therefore, this study was carried out to understand the prevalence of red cell antibodies that are important in regularly transfused thalassemic patients.

\section{Methodology}

This is a retrospective descriptive study, carried out at Lady Ridgeway Hospital for Children, Colombo, Colombo North Teaching Hospital, Ragama and National Hospital, Kandy. Ethical approval was granted from the ethical review committee of National Blood Transfusion Service, Sri Lanka.

Every patient with Beta Thalassaemia Major transfused with packed red cells issued from the blood banks

Ceylon Medical Journal 2021; 66: 96-99

DOI: http://doi.org/ 10.4038/cmj.v66i2.9472

${ }^{1}$ National Blood Transfusion Service, Ministry of Health, Sri Lanka.

Correspondence: SS, e-mail: <s.k.senavirathna@gmail.com>. Received 09 February 2021 and revised version 27 May 2021 accepted 15 June 2021

This is an open-access article distributed under the terms of the Creative Commons Attribution License, which permits unrestricted use, distribution, and reproduction in any medium, provided the original author and source are credited. 
of those hospitals were included from $1^{\text {st }}$ of October 2019 to $31^{\text {st }}$ of December 2019. As patients with beta thalassaemia major undergo regular blood transfusion monthly, it was possible to include all patients of these hospitals in this study. Routine crossmatch includes an antibody screening; therefore, the results of the testing were collected together with other demographic data. Routine antibody screening is performed with tube technique, in which patient's serum is tested against a panel of red cells to cover all common red cell antigens. When antibody screening is positive, antibody identification is carried out at the immunohaematology reference laboratory of the National Blood Centre, Colombo.

Data were entered into a spreadsheet and analysed using "Numbers” (Apple Inc.) spreadsheet software.

\section{Results}

There were 398 patients in all hospitals. 188 (47.24\%) of them were males and 210 (52.76\%) were females. Mean age was 18.41 ( $\mathrm{SD}=11.67$ ) years. In terms of blood groups, the commonest $\mathrm{ABO}$ group was group $\mathrm{O}(\mathrm{n}=174,43.72 \%)$, followed by group B (n=108, 27.14\%). Group A and Group AB were 93 (23.37\%) and 23 (5.78\%) respectively. As far

Table 1. Distribution of $A B O$ and RhD status

\begin{tabular}{lcc}
\hline Blood Group & Number of patients & Percentage \\
\hline A Rh D Positive & 86 & 21.61 \\
A Rh D Negative & 7 & 1.76 \\
B Rh D Positive & 102 & 25.63 \\
B Rh D Negative & 6 & 1.51 \\
AB Rh D Positive & 23 & 5.78 \\
AB Rh D Negative & 0 & 0 \\
O Rh D Positive & 166 & 41.71 \\
O Rh D Negative & 8 & 2.01 \\
\hline
\end{tabular}

as Rhesus D antigen (Rh D) is considered, 377 (94.72\%) patients were positive for Rh D, while 21 (5.28\%) were negative. Table 1 describes their ABO groups with Rh D status.

All major Rh antigen (C, E, e, c) typing was introduced recently and it needs a transfusion free period of three months. So that, it is performed usually prior to the first transfusion, even though a probable phenotype is determined after detection an antibody. Therefore, Rh phenotypes are available only in 81 patients and Table 2 presents their distribution according to the Wiener nomenclature. All of these patients were negative for Kell (K) antigen.

Out of 398 patients, unexpected red cell antibodies are present only in $6(1.51 \%)$ patients. Identified antibodies are described in Table 3. Interestingly, there was one patient who had developed multiple antibodies.

Table 2. Probable Rh Phenotypes of the patients who have undergone Rh phenotyping

\begin{tabular}{lcc}
\hline Rh Phenotype* & Number of patients & Percentage \\
\hline $\mathrm{R}_{1} \mathrm{R}_{1}$ & 48 & 59.26 \\
$\mathrm{R}_{1} \mathrm{r}$ & 23 & 28.39 \\
$\mathrm{R}_{2} \mathrm{R}_{2}$ & 1 & 1.23 \\
$\mathrm{R}_{2} \mathrm{r}$ & 1 & 1.23 \\
$\mathrm{R}_{1} \mathrm{R}_{2}$ & 3 & 3.71 \\
$\mathrm{R}^{0} \mathrm{r}$ & 1 & 1.23 \\
$\mathrm{rr}$ & 4 & 4.95 \\
\hline
\end{tabular}

*This Wiener nomenclature is convenient for verbal communication. The uppercase letter $\mathrm{R}$ is used to indicate the presence of $\mathrm{D}$ antigen,whereas the lowercase letter $r$ is used when $\mathrm{D}$ is absent. R represents $\mathrm{C}$,e antigens while $\mathrm{R}_{2}$ indicates $\mathrm{c}, \mathrm{E}$ antigen combination. $\mathrm{R}_{0}$ and $\mathrm{R}_{\mathrm{z}}$ show c,e and C,E combinations respectively. With $\mathrm{r}$, prime (') is used if a C,e combination is present whereas double prime (") is used to represent c,E. C,E combination with $r$ is stated as $\mathrm{r}^{\mathrm{y}}[2]$.

Table 3. Patients who have developed red cell antibodies

\begin{tabular}{|c|c|c|c|c|c|}
\hline & Age & Gender & Blood group & Probable Rh Phenotype & Red cell antibodies identified \\
\hline Patient 1 & 12 years & Female & O Rh D Positive & $\mathrm{R}_{1} \mathrm{R}_{1}$ & Anti E \\
\hline Patient 2 & 22 years & Female & B Rh D Positive & $\mathrm{R}_{1} \mathrm{R}_{1}$ & Anti E \\
\hline Patient 3 & 42 years & Male & B Rh D Negative & $\mathrm{rr}$ & $\begin{array}{l}\text { Anti D, Anti C, Anti E, } \\
\text { Anti K, Anti S, Anti } \mathrm{Jk}^{\mathrm{b}}\end{array}$ \\
\hline Patient 4 & 21 years & Female & O Rh D Positive & $\mathrm{R}_{1} \mathrm{r}$ & Anti K \\
\hline Patient 5 & 13 years & Female & B Rh D Positive & $\mathrm{R}_{1} \mathrm{R}_{2}$ & Anti K \\
\hline Patient 6 & 11 years & Male & AB Rh D Positive & $\mathrm{R}_{1} \mathrm{R}_{1}$ & Anti E with autoantibodies \\
\hline
\end{tabular}


The commonest antibody is Anti E ( $\mathrm{n}=4)$, followed by Anti $\mathrm{K}(\mathrm{n}=3)$. In addition to these six patients, there were 2 patients who had developed only autoantibodies.

\section{Discussion}

In beta thalassaemia major there is abnormal production of haemoglobin and regular red cell transfusion is the standard treatment by which the abnormal erythropoiesis is suppressed. Transfusion management of patients with thalassaemia has many challenges, including red cell antibody formation that can complicate the transfusion management. Therefore, estimation of prevalence of red cell antibodies is crucial in the regular follow up.

According to the results, developing red cell antibodies is not common in the study population. Comparing the results with similar studies, would be beneficial to come to a conlusion.

There are studies carried out worldwide to estimate red cell alloimmunization in frequently transfused patients. In Asia, as Thalassaemia Major is a common transfusion dependent condition, studies have been performed in Thalassaemic patients. In other countries Sickle Cell Disease is also considered.

A similar study carried out in Pakistan has shown that 30 patients out of 800 (3.75\%) regularly transfused patients have developed red cell antibodies. Antibodies were belonged to Rh, Kell, Duffy and Lewis blood group systems [5]. According to this study antibody formation was not related to the number of previous red cell transfusion. They have recommended that to prevent red cell antibodies all thalassaemic patients should receive antigen matched red cells. A study done in India revealed that alloimmunization rate of $18.8 \%$ and their common antibodies were in the Rh blood group system [6]. They also have recommended to transfusing phenotypically matched blood for regularly transfused patients to reduce the occurrence of red cell alloantibodies. Those studies emphasize the importance of Rh phenotype matching for blood transfusion in thalassaemia patients.

In a thalassaemia centre in Iran, red cell antibodies were detected in 9 patients out of 90 patients selected (10\%), with Anti K as the commonest antibody [7]. They have revealed that there is no correlation between the age at first transfusion, frequency of transfusion and alloantibody formation. Another study from Iran has revealed alloantibody formation in $4 \%$ and the commonest antibody was Anti K [8]. In a case report from Southern China red cell alloantibodies together with autoantibodies have been detected [9]. According to a study done in Egypt 23.8\% of children with thalassaemia major were found to have red cell alloantibodies, Anti K being the commonest [10]. A multicentre study carried out in Iran revealed that $18.8 \%$ patients had single red cell alloantibody and 3\% had multiple antibodies. Anti K was the commonest and $\mathrm{Rh}$ antibodies were second in common [11]. However, those studies do not reveal any risk factors to predict antibody development.

A study done in Caspian Sea coastline including 190 patients revealed the occurrence of red cell antibodies in 24.7\% patients, commonly Anti K followed by Rh antibodies. In $6.3 \%$ there were multiple antibodies [12]. Alloimmunization was found in $5.64 \%$ in a study performed including 319 patients in India. Antibody specificities were in the Kell, Rh, Kidd and Xg blood group systems [13]. Another study done in Eastern India evaluating 500 patients with thalassaemia major has shown an incidence of $5.6 \%$ in alloimmunization and $1 \%$ had auto antibody formation [14]. A study among 100 patients carried out in Bangladesh revealed antibody detection in $6 \%$ of patients [15]. A study done in a children's hospital in Philadelphia has revealed that in patients with Sickle cell disease there $58 \%$ of tested patients have developed red cell antibodies despite of receiving phenotypically matched blood [16].

Those studies shows that, among the detected antibodies Rh and Kell antibodies are the commonest, hence some centres use Rh and Kell matched red cell units for regularly transfused patients. However, provision of phenotypically matched blood to those patients is still debatable considering the cost of Rh and Kell phenotyping. Prevalence of antibody formation in our study is low compared to other related studies done in various parts of the world. This could be due to ethnical variations in immunogenicity of the population.

\section{Conclusion}

Low prevalence of red cell antibodies in this study was revealed, even without matching Rh and Kell antigens. Although the commonest identified antibodies are in Rh and Kell systems, it is worthwhile to do further large-scale studies to evaluate cost effectiveness in phenotypically matched red cell transfusion in beta thalassaemia patients.

\section{Authors' contributions}

All authors involved in conception and design of the study and in data collection. SS involved in data analysis and initial drafting of report. LR involved in interpretation of analyzed data, critically reviewing of the report for important intellectual content. All authors read and approved the final version of the manuscript.

\section{Conflicts of Interest}

There are no conflicts of interest.

\section{Acknowledgements}

Authors acknowledge staff of the National blood Transfusion Service of Sri Lanka. 


\section{Ethics approval}

Ethical approval was granted from the ethical review committee of National Blood Transfusion Service, Sri Lanka.

\section{Source of funding}

Nil.

\section{References}

1. Murphy MF, Pamphilon DH, Heddle NM. Practical Transfusion Medicine. 4 ed. Oxford, UK: John Wiley \& Sons Ltd, 2013.

2. Harmening D. Modern Blood Banking and Transfusion Practices. 6 ed. Philadelphia: F. A. Davis Company, 2012.

3. Milkins C, Berryman J, Cantwell C, et al. Guidelines for pre-transfusion compatibility procedures in blood transfusion laboratories. Transfus Med 2013; 23(1): 3-35.

4. Anonymous, National Haemovigillance Report 2017, National Blood Transfusion Service, Sri Lanka.

5. Usman M, Moin S, Moinuddun M, et al. Frequency of Red Cell Alloimmunization Among Patients with Transfusion Dependent Beta Thalassemia in Pakistan. IJHO 2011; 21(3): 166-70.

6. Chaudhari CN. Red Cell Alloantibodies in Multiple Transfused Thalassaemia Patients. MJAFI 2011; 67: 34-7.

7. Obeidi N, Mankhian AR, Hatami G, et al. Antibody Screening in Patients With Thalassemia Major. Labmedicine 2011; 42(10): 618-22.

8. Vaziri M, Shahshahani HJ, Moghaddam M, et al. Prevalence and specificities of red cell alloantibodies in transfusion- dependent beta thalassemia patients in Yazd. IJPHO 2015; 5(2): 93-100.

9. Song Z, Zou Y. Blood group serology analysis of one rare case of $\beta$ - thalassemia major with cold autoantibodies and alloantibodies. J Med Lab Diagn 2016; 7(5): 28-31.

10. Osman NF, Ragab SA, Soliman MA. Alloimmunization in Egyptian children with transfusiondependent Betathalassaemia: a major challenge. Egypt J Haematol 2017; 42(1): 9-13.

11. Azarkeivan A, Ansari S, Ahmadi MH, et al. Blood Transfusion and Alloimmunization in Patients with Thalassemia: Multicenter Study. Pediatr Hematol Oncol. 2011; 28(4): 479-85.

12. Davoudi-Kiakalayeh A, Mohammadi R, Pourfathollah AA, Siery Z, Davoudi-Kiakalayeh S. Alloimmunization in Thalassemia Patients: New Insight for Healthcare. Int $J$ Prev Med. 2017; 8(1): 101-5.

13. Dhawan HK, Kumawat V, Marwaha N, et al. Alloimmunization and autoimmunization in transfusion dependent thalassemia major patients: Study on 319 patients. Asian Journal of Transfus Sci. 2014; 8(2): 84-8.

14. Datta SS, Mukherjee S, Talukder B, Bhattacharya P, Mukherjee K. Frequency of Red Cell Alloimmunization and Autoimmunization in Thalassemia Patients: A Report from Eastern India. Adv Hematol. 2015; 2015: 1-6.

15. Sultana N, Rahman A, Easmin F, et al. Identification of Rh alloantibody in Thalassaemia Patients. J Medicine. 2016; 17: 79-83.

16. Chou ST, Jackson T, Vege S, et al. High prevalence of red blood cell alloimmunization in sickle cell disease despite transfusion from Rh-matched minority donors. Blood 2013; 122(6): 1062-73. 